\title{
Determination of Degree of Cure of
} I SOTHERMALLY AGED LX-13

\author{
G. L. Clink
}

DEVELOPMENT DIVISION MU

JANUARY - MARCH 1976

P. O. 03-5438

Normal Process Development Endeavor No. 102

Sandia Laboratories

Albuquerque, New Mexicó

\section{,}

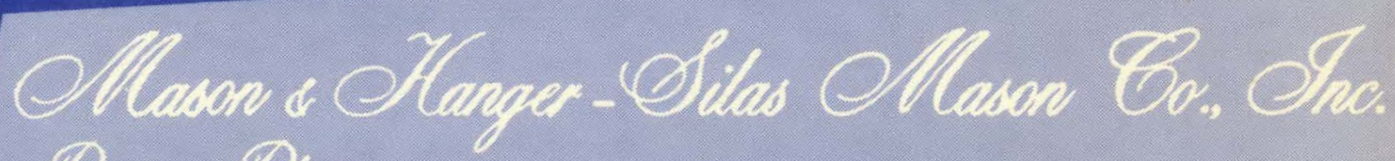
conver Colent P. 0. Box 607

amanmo, T32as 79177

$006-035-1501$

apciated tor the

ENERCY RESEARCH ANO OEVELOPMENT ADWINISTEGTION aniler

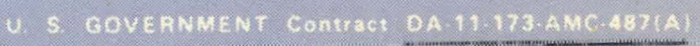




\section{DISCLAIMER}

This report was prepared as an account of work sponsored by an agency of the United States Government. Neither the United States Government nor any agency Thereof, nor any of their employees, makes any warranty, express or implied, or assumes any legal liability or responsibility for the accuracy, completeness, or usefulness of any information, apparatus, product, or process disclosed, or represents that its use would not infringe privately owned rights. Reference herein to any specific commercial product, process, or service by trade name, trademark, manufacturer, or otherwise does not necessarily constitute or imply its endorsement, recommendation, or favoring by the United States Government or any agency thereof. The views and opinions of authors expressed herein do not necessarily state or reflect those of the United States Government or any agency thereof. 


\section{DISCLAIMER}

Portions of this document may be illegible in electronic image products. Images are produced from the best available original document. 


\section{NOTICE}

This report was prepared as an account of work sponsored by the United States Government. Neither the United States nor the United States Energy Research and Development Administration, nor their employees, nor any of their contractors, subcontractors, or their employees, makes any warranty, express or implied, or assumes any legal liability or responsibility for the accuracy, r.nmpleteness or usefulness of any information, apparatus, product or process disclosed, or represents that its use would not infringe privately-owned rights. 


\title{
Determination of Degree of Cure of ISOTHERMALLY AGED LX-13
}

\author{
G. L. Clink \\ DEVELOPMENT DIVISION \\ January - March 1976 \\ Endeavor No. 102 \\ P. 0. 03-5438
}

B-1

DISTRIBUTION OF THIS DOCUMENT IS UNLINTIE E 


\section{ABSTRACT}

An isothermal aging study of uncured $L X-13$ was undertaken to gain some insight into the chemical and physical cure of this material as a function of temperature.

Uncured LX-13 samples were isothermally aged at $3.5,22,52$, and $68 \mathrm{C}$, for various elapsed times. The resultant isothermal residues were analyzed for degree of chemical cure and for hardness as a function of time and temperature through NMR spectrometry and Shore durometer measurements.

\section{EXPER I MENTAL}

Samples were prepared by rolling an LX-13 patty to relatively uniform thickness(1). Individual samples in the form of right circular cylinders (cores) were made by use of a stainless steel cork borer, and were approximately $4 \mathrm{~mm}$ in diameter and 7-8 $\mathrm{mm}$ in length. Sufficient number of these cores were made such that three samples were available for each selected elapsed time. The sample cores were placed in petri dishes and stored in covered containers at $3.5,22,52$, and $68 \mathrm{C}$. Durometer measurement samples were approximately 7-8 $\mathrm{mm}$ thick and 15-18 $\mathrm{mm}$ square. . These also were placed in petri dishes and stored as the others. Only one square per elapsed time measurement was required for durometer data due to the sufficient area for several measurements on each surface.

At various elapsed times, core samples were removed, weighed, and placed in a septum vial along with 1 me of a $50 / 50$ ( $V$ ) mixture of $d^{6}$ benzene/ $d^{6}$ acetone. A weighed amount of tetramethoxysilane (TMOS) was also added to each sample to serve as an internal quantitative standard. After closure with a septum, they were placed on a Kahn mechanical shaker for several hours until complete dissolution of PETN and unbound Sylgard was effected. As the degree of cure increases with time, a soft gelatinous core remains undissolved. Previous studies have shown that all the PETN has been removed and is in solution along with the Sylgard extractables. This solution is placed in a standard $5 \mathrm{~mm}$ NMR tube, along with $0.05 \mathrm{ml}$ of benzene to serve as an internal lock material, and analyzed on a Varian HA-100 through routine integration techniques. All three species are single peak systems, thus placing the integration results at an optimum point. Physical cure (hardness) is monitored by durometer measurements taken at various locations on the $L X-13$ squares. The Shore durometer used was a Model "A-2" (ASTM 2240) as the size of the sample squares required a smaller measurement contact surface than normally used.

(1) PX Lot 20-76-0127-217. This material was not deaerated after milzing, to eliminate the lengthy room temperature contact. 


\section{LX-13 AGING AT $3.5 \mathrm{C}(38 \mathrm{~F})$}

Table I and Fig. 1 present the results of chemical aging of the material at $3.5 \mathrm{C}$, as outlined in the previous section. Table II and Fig. 2 contain the results of Shore durometer measurements of this system. Fig. 3 displays the relative trends of hardness cure and chemical cure, the latter shown as percent of original polydimethylsiloxane unextractable.

\section{LX-13 AGING AT 22 C (72 F)}

The chemical analysis and hardness measurement results for the $22 \mathrm{C}$ system are presented in Table III and Fig. 4, and in Table IV and Fig. 5, respectively. Behavioral comparison of the two is presented in Fig. 6 .

\section{LX-13 AGING AT 52 C (126 F)}

Chemical and hardness data for this system are presented in Table $V$ and Fig. 7 and Table VI and Fig. 8, respectively. Behavioral comparison is presented in Fig. 9.

\section{LX-13 AGING AT 68 C (154 F)}

Chemical and hardness data for this system are presented in Table VII and Fig. 10, and in Table VIII and Fig. 11, respectively. Comparison of cure curves is presented in Fig. 12.

Fig. 13 presents comparison of the chemical cure curves for the four temperatures studied $(3.5,22,52$, and $68 \mathrm{C})$.

Fig. 14 presents comparison of the hardness curves obtained in the four systems.

In considering the four isothermal systems, at a common percent polydimethylsiloxane retention point, there should exist a linear relationship between the reciprocal temperature $(K)$ and the $\log$ of the elasped time. In previous studies of the Sylgard system, an arbitrary retention point of $50 \%$ was chosen. However, in this study, the $3.5 \mathrm{C}$ system was monitored only up to 1273 hours, with a final polydimethylsiloxane retention of $37.5 \%$; in order to include the $3.5 \mathrm{C}$ system data, an arbitrary retention point of $30 \%$ was chosen. The results are presented in Fig. 15. The data show a relatively good linear adherence for the four isothermal systems, at least up to this point.

\section{COMMENTS}

This completes the data gathering portion of the $L X-13$ cure study. Determination of system kinetics parameters will be completed by J. Holovka, Sandia Laboratories, Albuquerque, New Mexico. 
Table I. Polydimethylsiloxane Extractables $(L X-13)$ 3.5.C

\begin{tabular}{|c|c|c|c|c|c|c|}
\hline \multirow{2}{*}{$\begin{array}{c}\text { Elapsed } \\
\text { Time } \\
\text { (hrs) } \\
\end{array}$} & \multicolumn{5}{|c|}{ Percent Polydimethylsiloxane } & \multirow{2}{*}{$\begin{array}{c}\text { Percent } \\
\text { Extractables } \\
\end{array}$} \\
\hline & 1 & 2 & 3 & Average & $\sigma$ & \\
\hline 0 & 19.9 & 20.0 & 19.9 & 19.9 & 0.06 & 99.5 \\
\hline 50 & 19.8 & 19.8 & 20.0 & 19.9 & 0.12 & 99.5 \\
\hline 98 & 19.7 & 19.6 & 19.7 & 19.7 & 0.06 & 98.5 \\
\hline 165 & 19.2 & 19.2 & 19.1 & 19.2 & 0.06 & 96.0 \\
\hline 215 & 18.6 & 18.5 & 18.7 & 18.6 & 0.10 & 93.0 \\
\hline 260 & 18.4 & 18.6 & 18.4 & 18.5 & 0.12 & 92.5 \\
\hline 332 & 17.8 & 17.8 & 17.8 & 17.8 & 0.00 & 89.0 \\
\hline 380 & 17.5 & 17.6 & 17.5 & 17.5 & 0.06 & 87.5 \\
\hline 428 & 17.1 & 17.0 & 17.0 & 17.0 & 0.06 & 85.0 \\
\hline 600 & 15.9 & 15.9 & 16.0 & 15.9 & 0.06 & 79.5 \\
\hline 769 & 14.5 & 14.5 & 14.6 & 14.5 & 0.06 & 72.5 \\
\hline 840 & 14.0 & 14.1 & 13.9 & 14.0 & 0.10 & 70.0 \\
\hline 937 & 13.6 & 13.6 & 13.8 & 13.7 & 0.12 & 68.5 \\
\hline 1009 & 13.4 & 13.3 & 13.5 & 13.4 & 0.10 & 67.0 \\
\hline 1105 & 12.9 & 13.0 & 13.0 & 13.0 & 0.06 & 65.0 \\
\hline 1273 & 12.6 & 12.6 & 12.4 & 12.5 & 0.12 & 62.5 \\
\hline
\end{tabular}




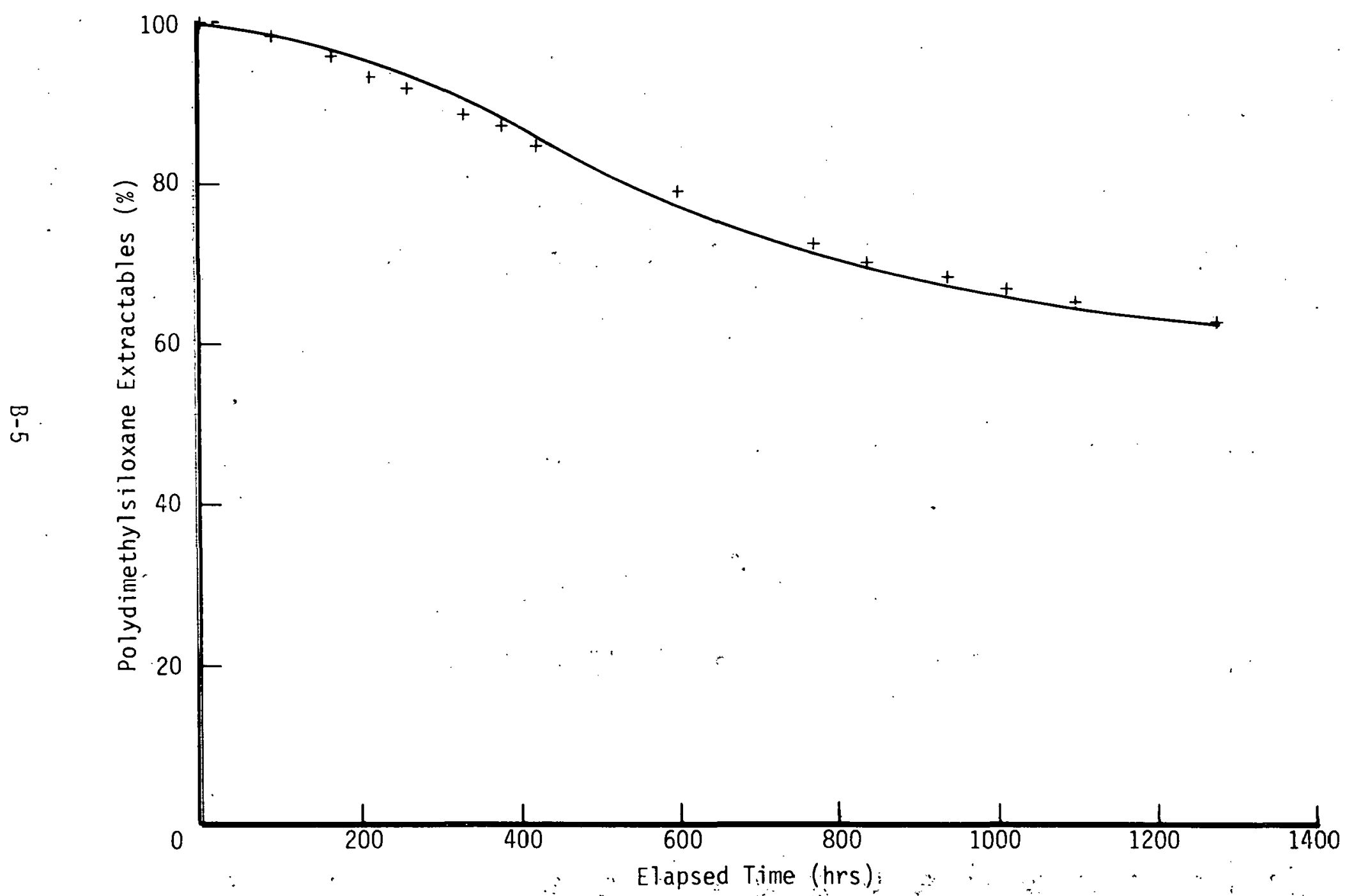

Fig. 1. LX-13 Polydimethylsiloxane Extractables (3.5 C) 
Table II. Durometer Measurements (LX-13) 3.5 .C

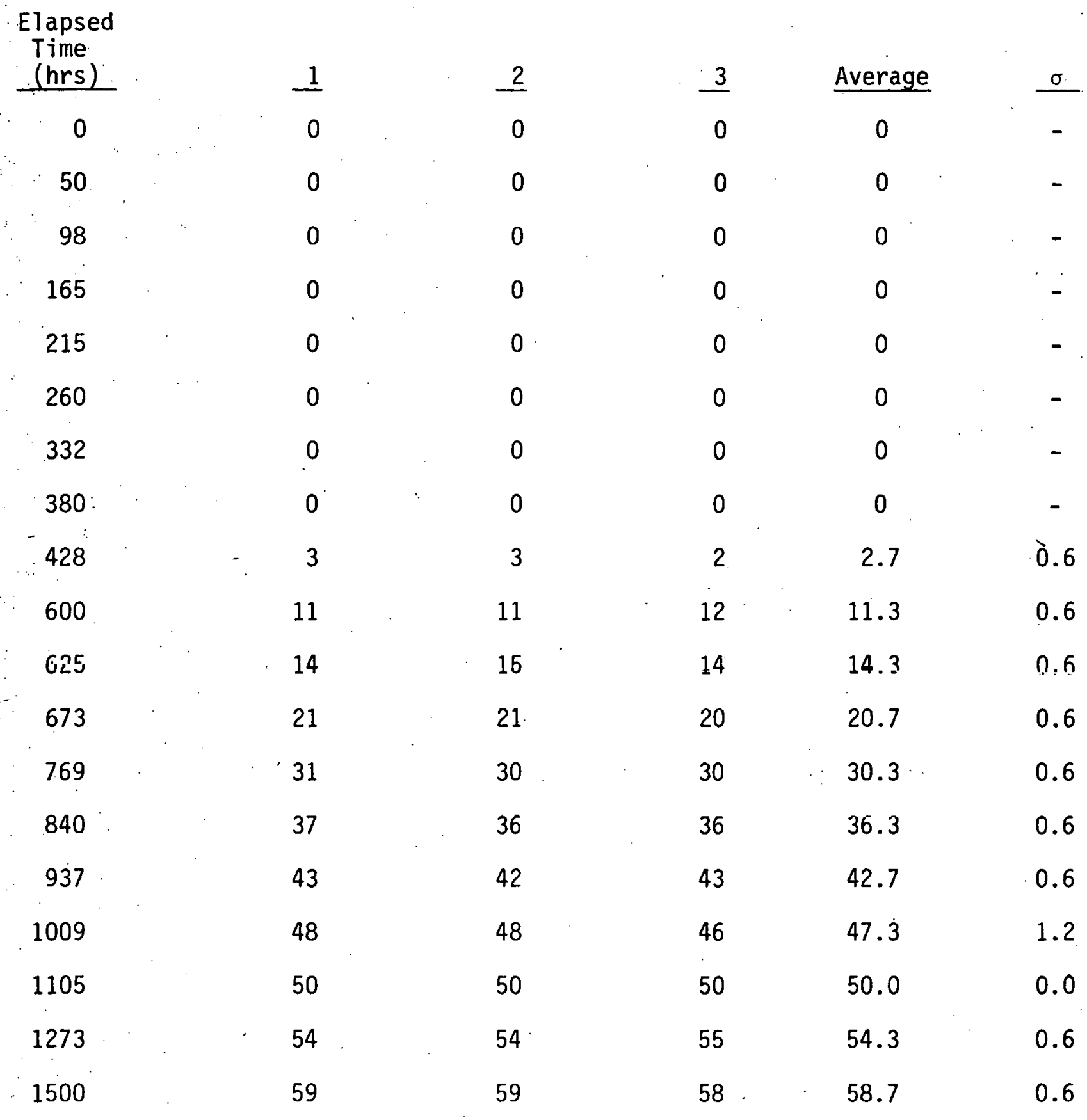




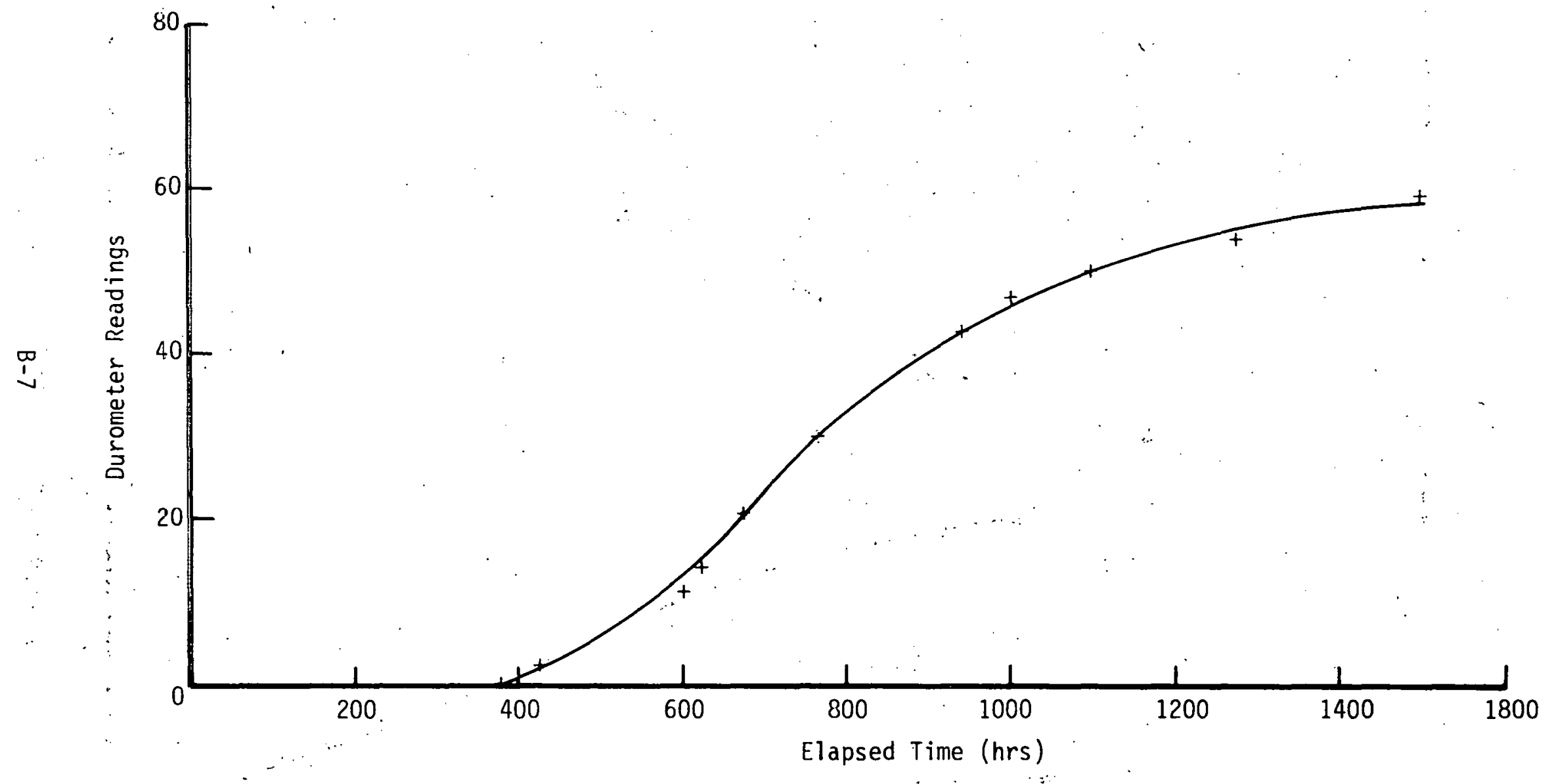

Fig. 2. LX-13 Durometer Measurements (3.5. C) 


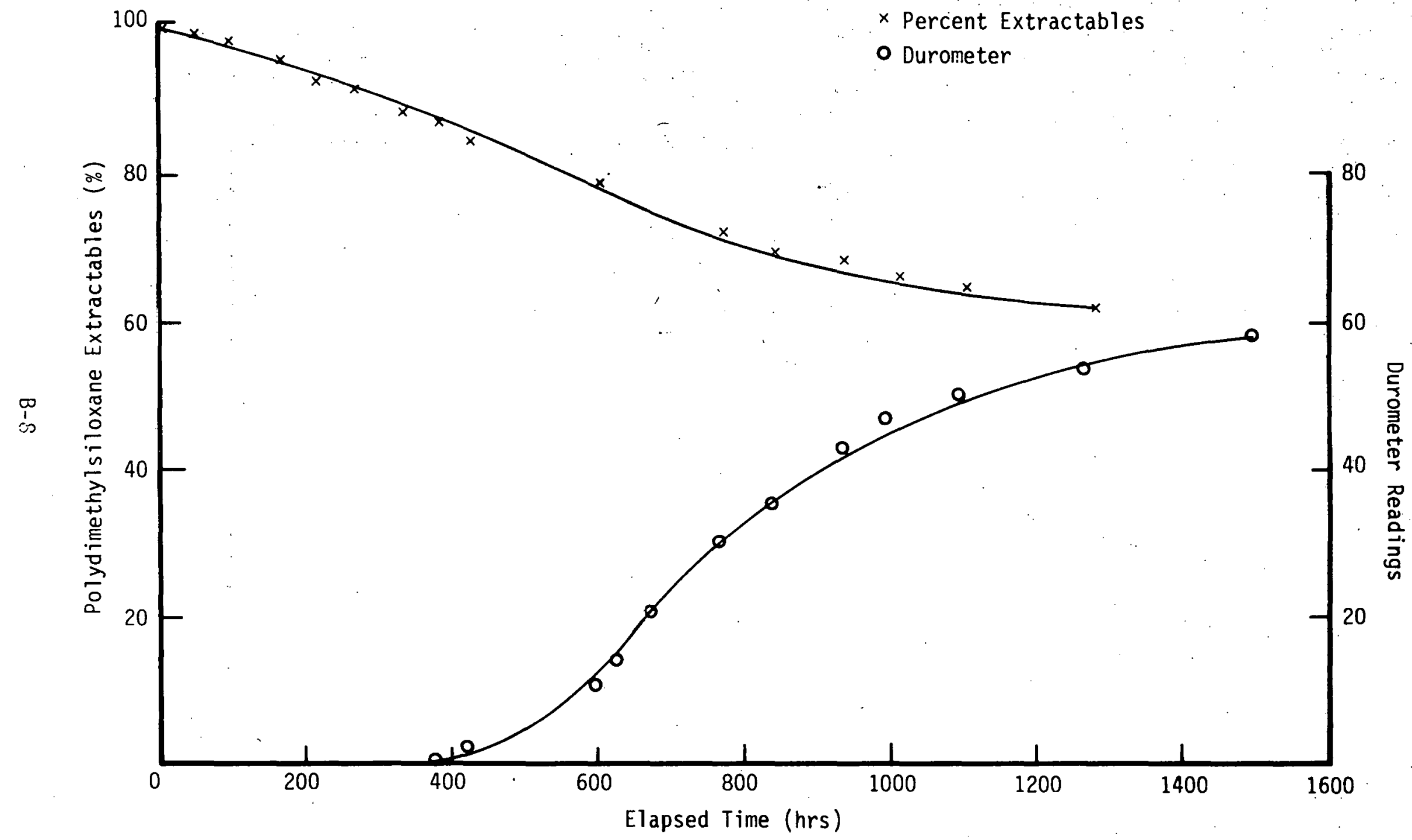

Fig. 3. LX-13 Comparison of Durometer Measurements with Percent Extractables ( $3.5 \mathrm{C})$ 
Table III. Polydimethylsiloxane Extractables (LX-13) $22 \mathrm{C}$

\begin{tabular}{|c|c|c|c|c|c|c|}
\hline \multirow{2}{*}{$\begin{array}{l}\text { Elapsed } \\
\text { Time } \\
\text { (hrs) } \\
\end{array}$} & \multicolumn{5}{|c|}{ Percent Polydimethylsiloxane } & \multirow{2}{*}{$\begin{array}{c}\text { Percent } \\
\text { Extractables } \\
\end{array}$} \\
\hline & 1 & 2 & 3 & Average & 0 & \\
\hline 0 & 19.9 & 19.9 & 19.9 & 19.9 & 0.00 & 99.5 \\
\hline 4.5 & 19.8 & 19.9 & 19.8 & 19.8 & 0.06 & 99.0 \\
\hline 20.3 & 19.3 & 19.4 & 19.4 & 19.4 & 0.06 & 97.0 \\
\hline 26.5 & 18.3 & 18.3 & 18.5 & 18.4 & 0,12 & 92.0 \\
\hline 45 & 16.6 & 16.5 & 16.5 & 16.5 & 0.06 & 82.5 \\
\hline 50 & 15.5 & 15.3 & 15.3 & 15.4 & 0.12 & 77.0 \\
\hline 68 & 13.5 & 13.5 & 13.3 & 13.4 & 0.12 & 67.0 \\
\hline 74 & 12.8 & 12.8 & 12.8 & 12.8 & 0.00 & 64.0 \\
\hline 92 & 11.6 & 11.7 & 11.6 & 11.6 & 0.06 & 58.0 \\
\hline 165 & 6.2 & 6.4 & 6.4 & 6.3 & 0.12 & 31.5 \\
\hline 189 & 5.1 & 5.1 & 5.3 & 5.2 & 0.12 & 26.0 \\
\hline 215 & 4.5 & 4.6 & 4.6 & 4.6 & 0.06 & 23.0 \\
\hline 260 & 3.9 & 4.1 & 4.1 & 4.0 & 0.12 & 20.0 \\
\hline
\end{tabular}




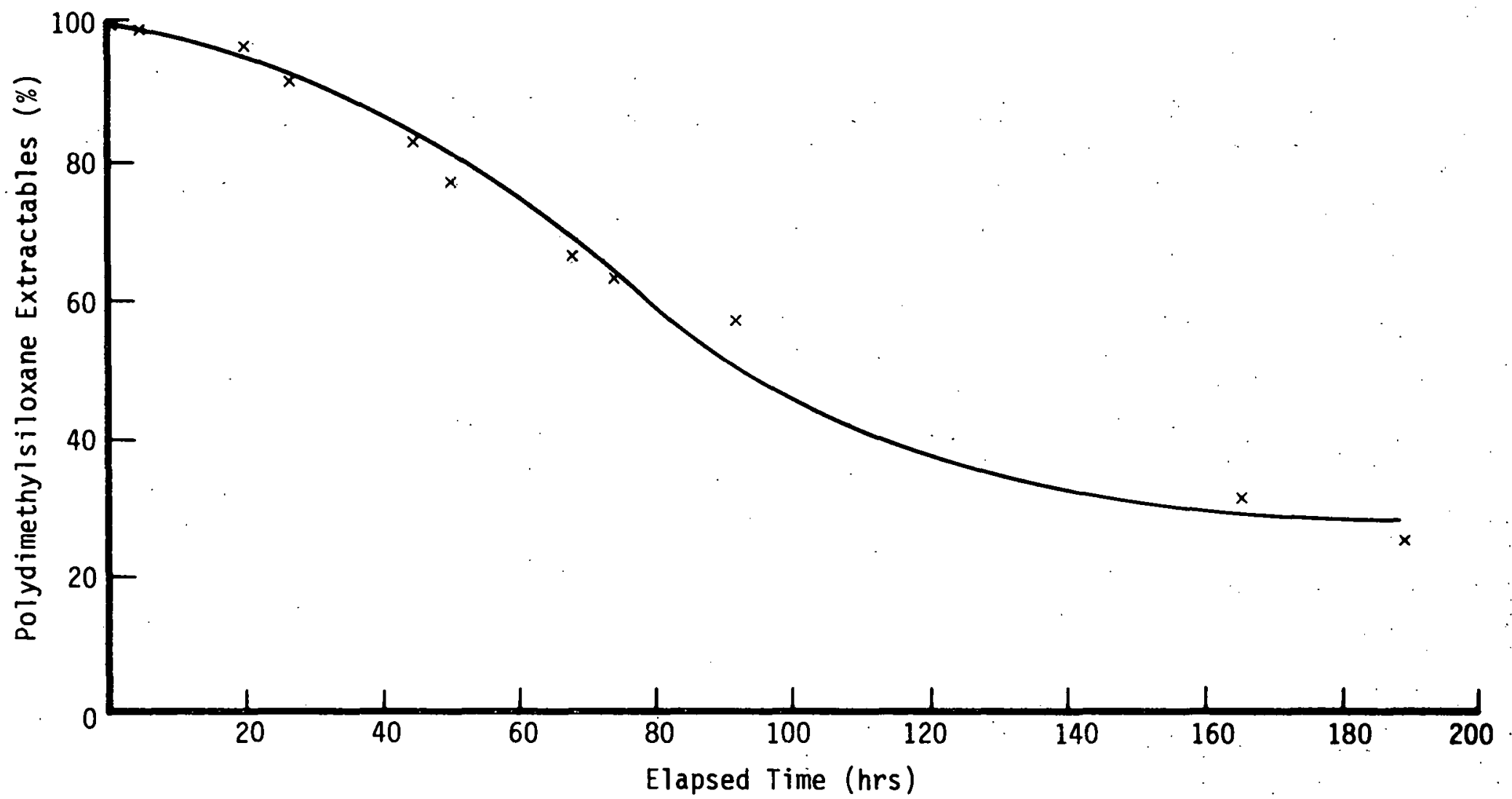

Fig. 4. LX-13 Polydimethylsiloxane Extractables (22 C) 
Table IV. Durometer Measurements $(L X-13) 22 \mathrm{C}$

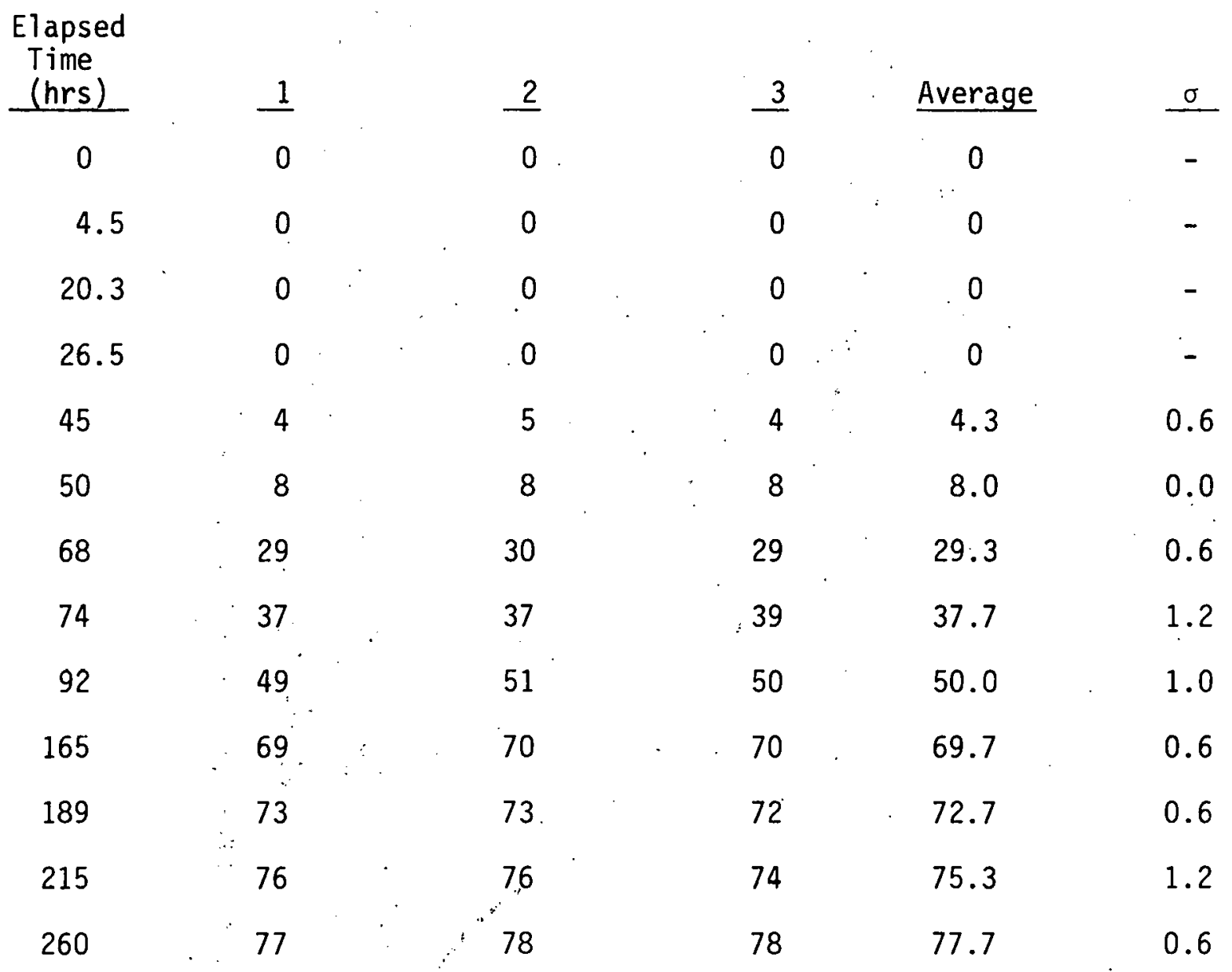




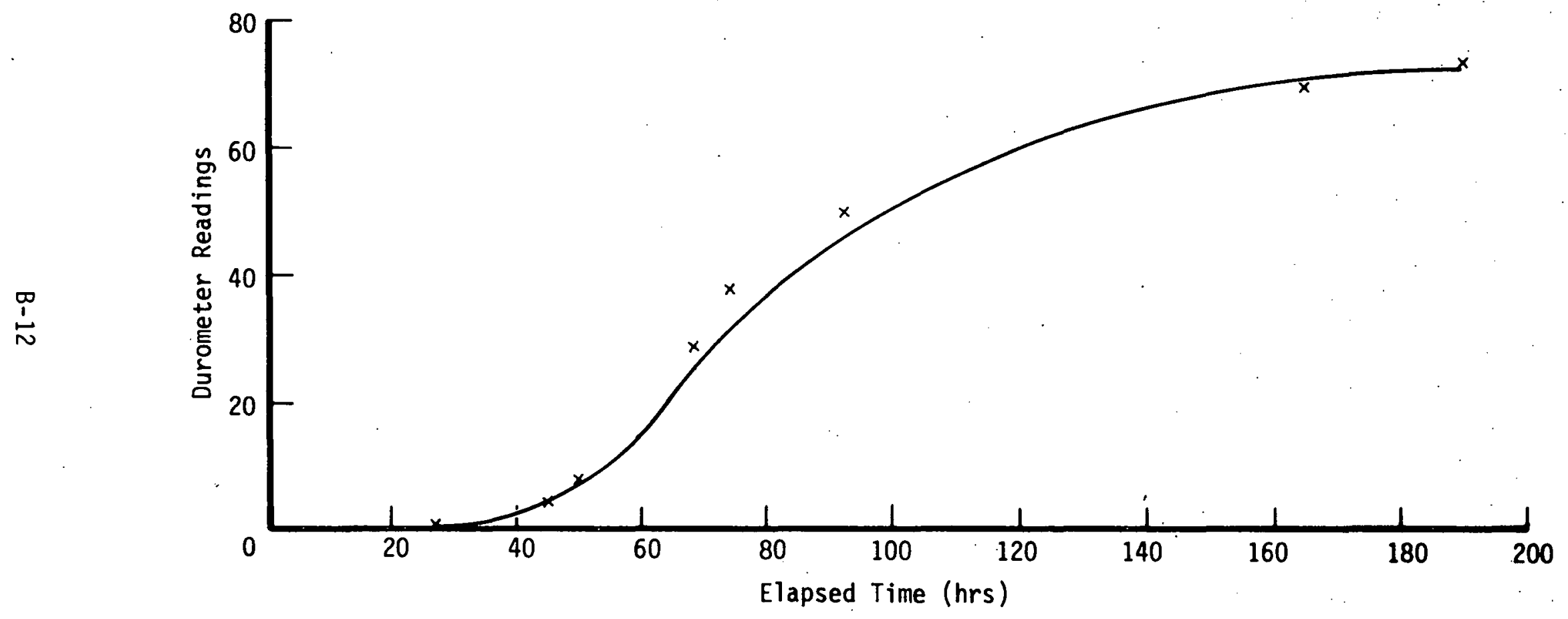

Fig. 5. LX-13 Durometer Measurements (22 C) 
$\times$ Percent Extractables

O Durometer

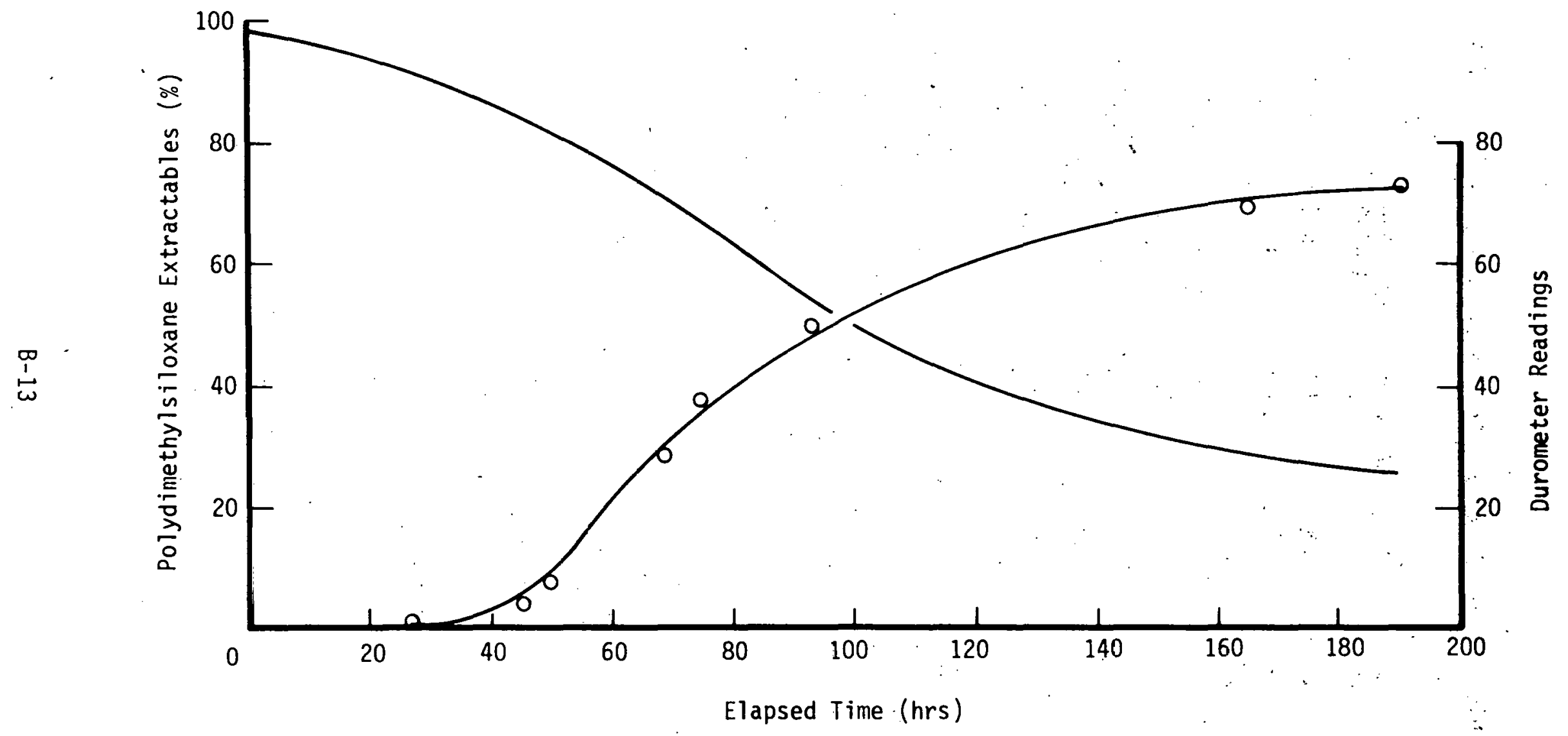

Fig. 6. LX-13 Comparison of Durometer Measurements with Percent Extractables (22 C) 
Table V. Polydimethylsiloxane Extractables (LX-13) $52 \mathrm{C}$

Elapsed

Time

(hrs)

0.0

1.0

1.5

2.0

3.0

4.0

5.0

5.8
Percent Polydimethylsiloxane

$1 \quad 2 \quad 3 \quad$ Average

19.9

19.9

19.9

18.5

10.6

8.8

5.8

4.8

4.1

3.6

3.6

3.7

4.7

$19.9 \quad 0.00$

$18.5 \quad 0.06$

$10.6 \quad 0.06$

$8.8 \quad 0.06$

$5.9 \quad 0.12$

$4.7 \quad 0.06$

$4.1 \quad 0.00$

$3.6 \quad 0.06$

Percent Extractables

99.5

93.0

53.0

44.0

29.5

23.5

20.5

18.0 


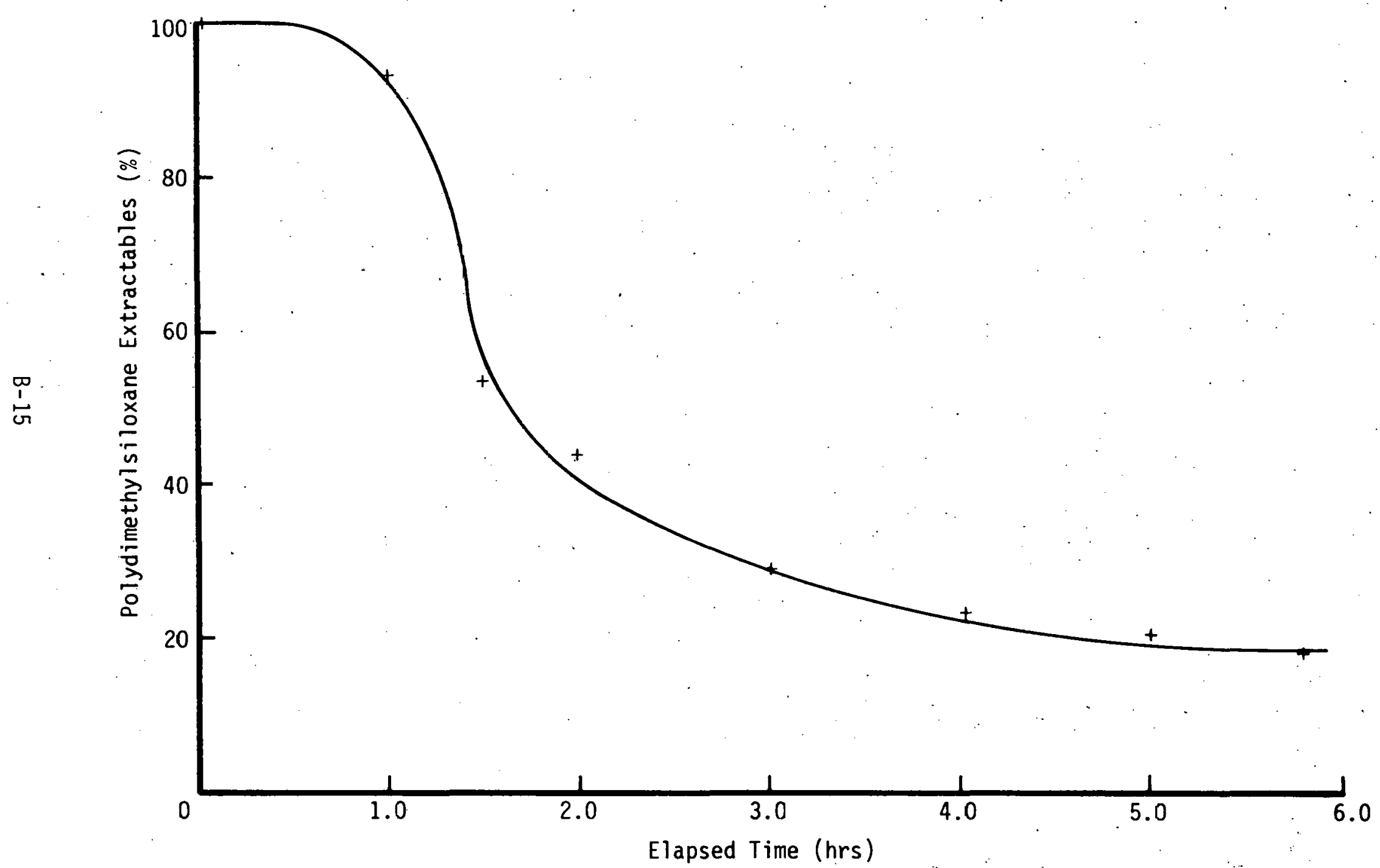

Fig. 7. LX-13 Polydimethylsiloxane Extractables (52 C) 
Table VI. Durometer Measurements (LX-13) $52 \mathrm{C}$

\begin{tabular}{cccccc}
$\begin{array}{c}\text { Elapsed } \\
\begin{array}{c}\text { Time } \\
\text { (hrs) }\end{array}\end{array}$ & $\frac{1}{2}$ & $\underline{2}$ & $\underline{3}$ & $\underline{\text { Average }}$ & $\frac{\sigma}{0}$ \\
\hline 0.0 & 0 & 0 & 0 & 0 & - \\
1.0 & 4 & 4 & 4 & 4 & 0.0 \\
1.5 & 15 & 15 & 13 & 14.3 & 1.2 \\
2.0 & 37 & 37 & 39 & 37.7 & 1.2 \\
3.0 & 57 & 57 & 55 & 56.3 & 1.2 \\
4.0 & 70 & 70 & 69 & 69.7 & 0.6 \\
5.0 & 77 & 77 & 77 & 77.0 & 0.0 \\
5.8 & 79 & 79 & 79 & 79.0 & 0.0
\end{tabular}




$$
L
$$




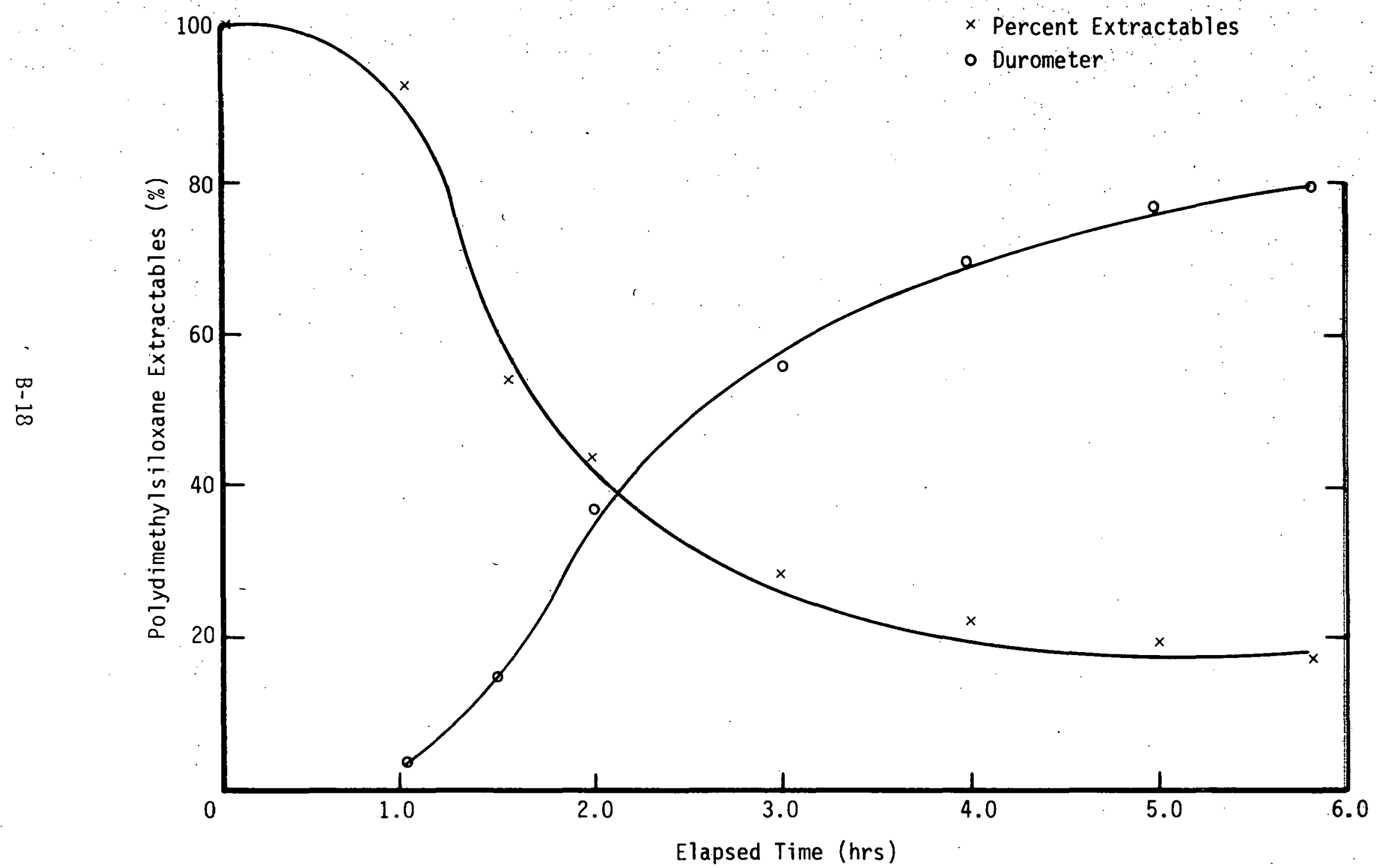

Fig. 9. LX-13 Comparison of Durometer Measurements with Percent Extractables (52 C) 
Table VII. Polydimethylsiloxane Extractables $(L X-13) 68 \mathrm{C}$

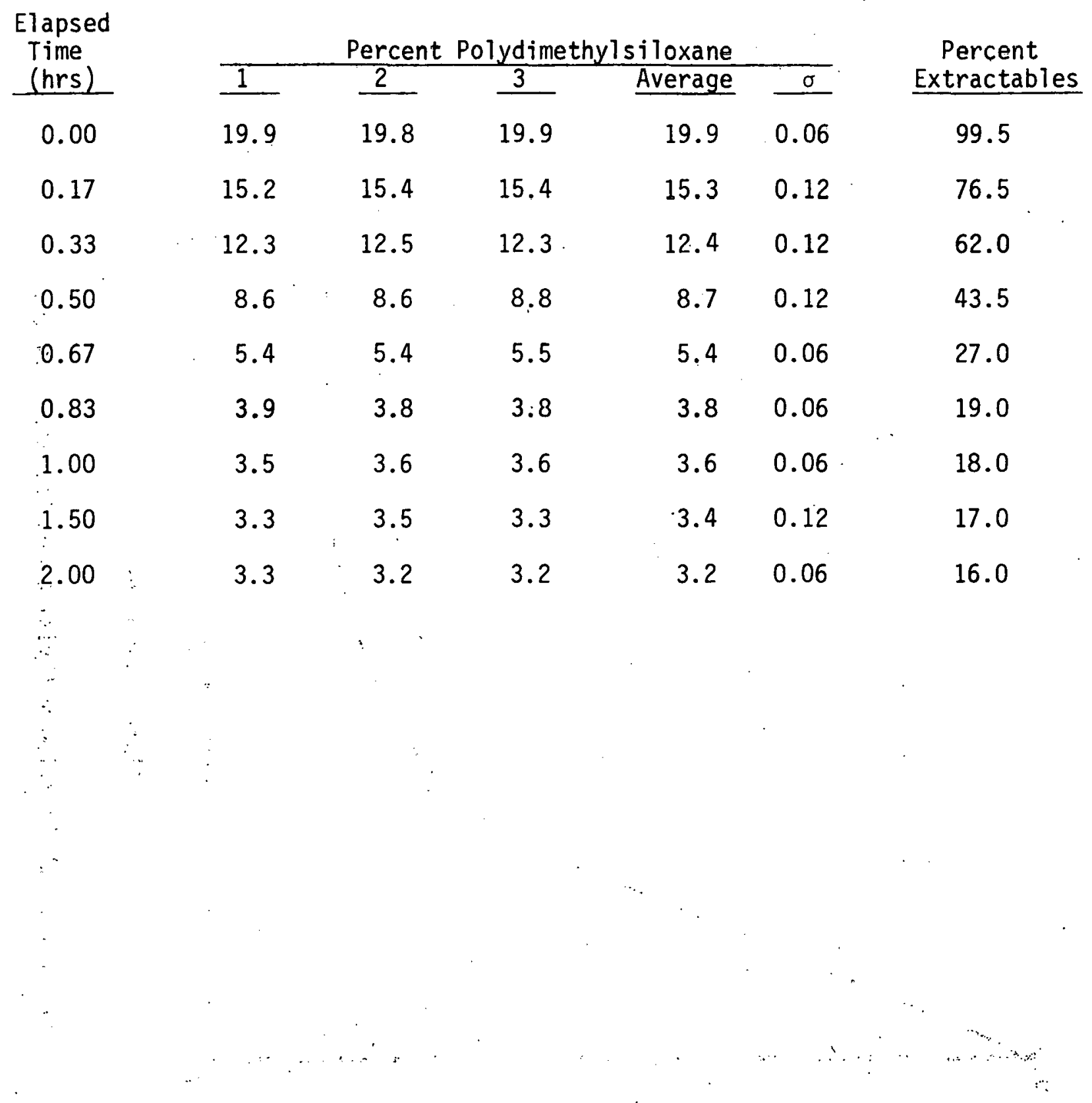




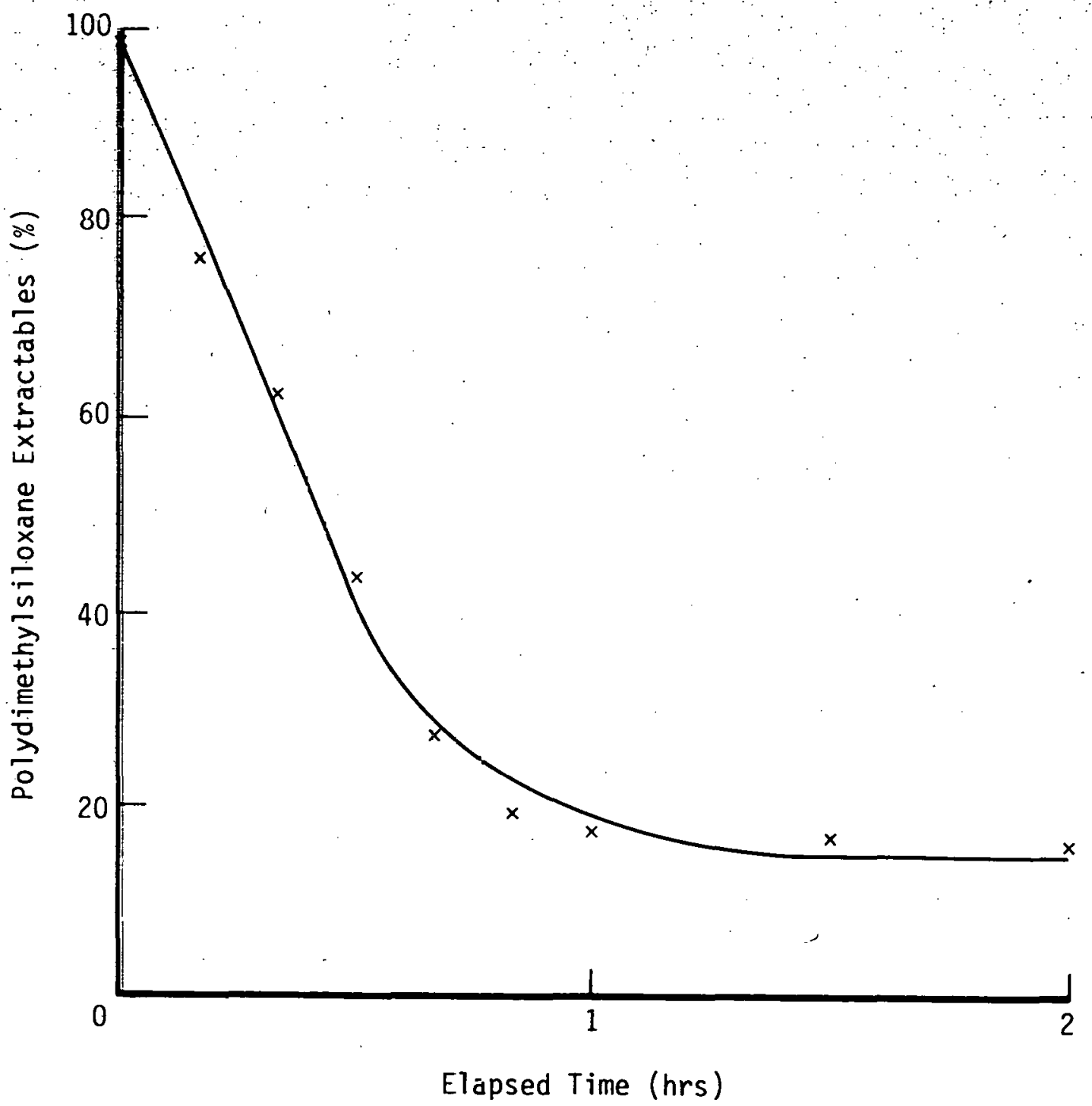

Fig. 10. LX-13 Polydimethylsiloxane Extractables (68 C) 
Table VIIİ. Durometer Measurements (LX-13) $68 \mathrm{C}$

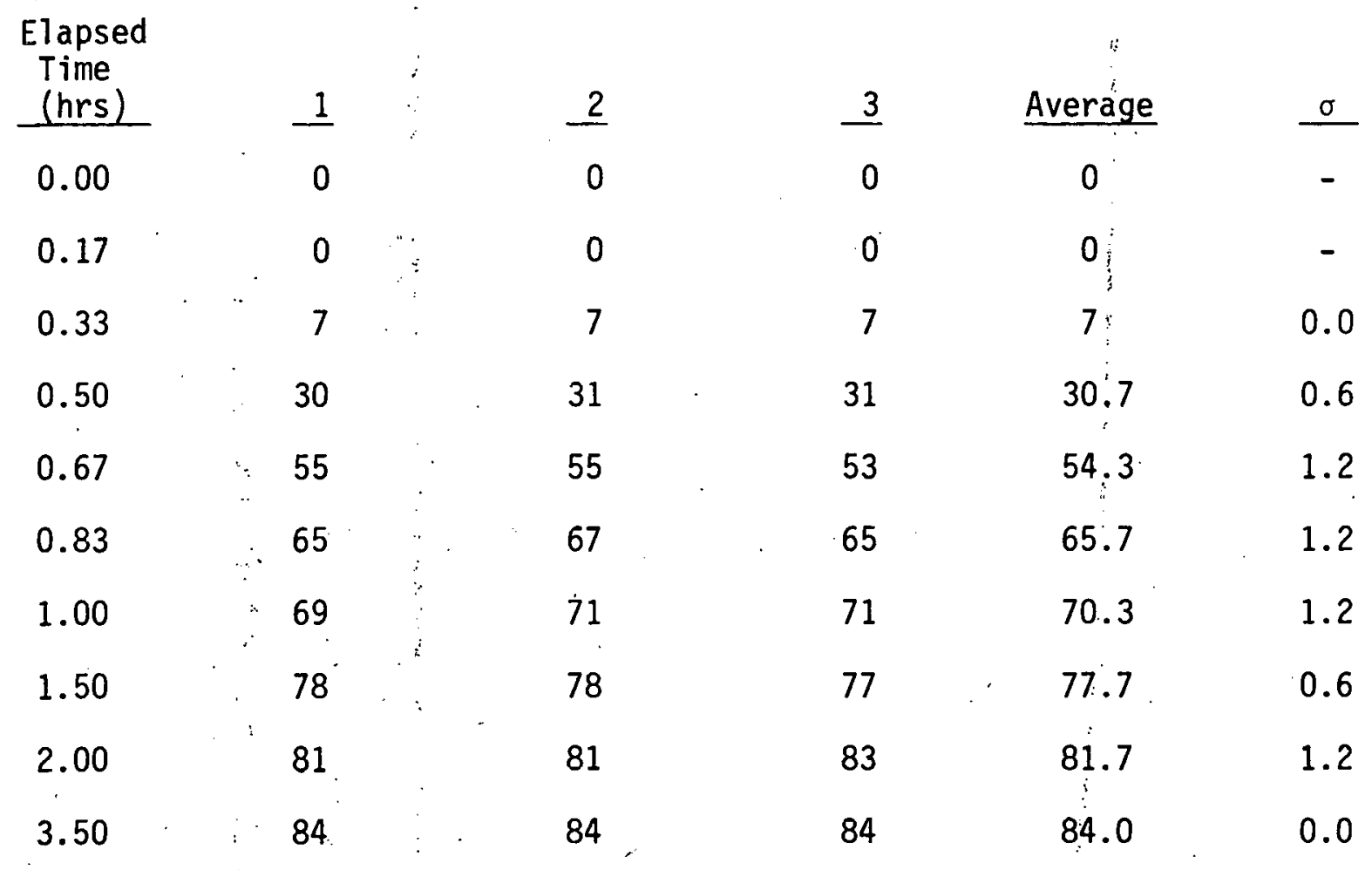




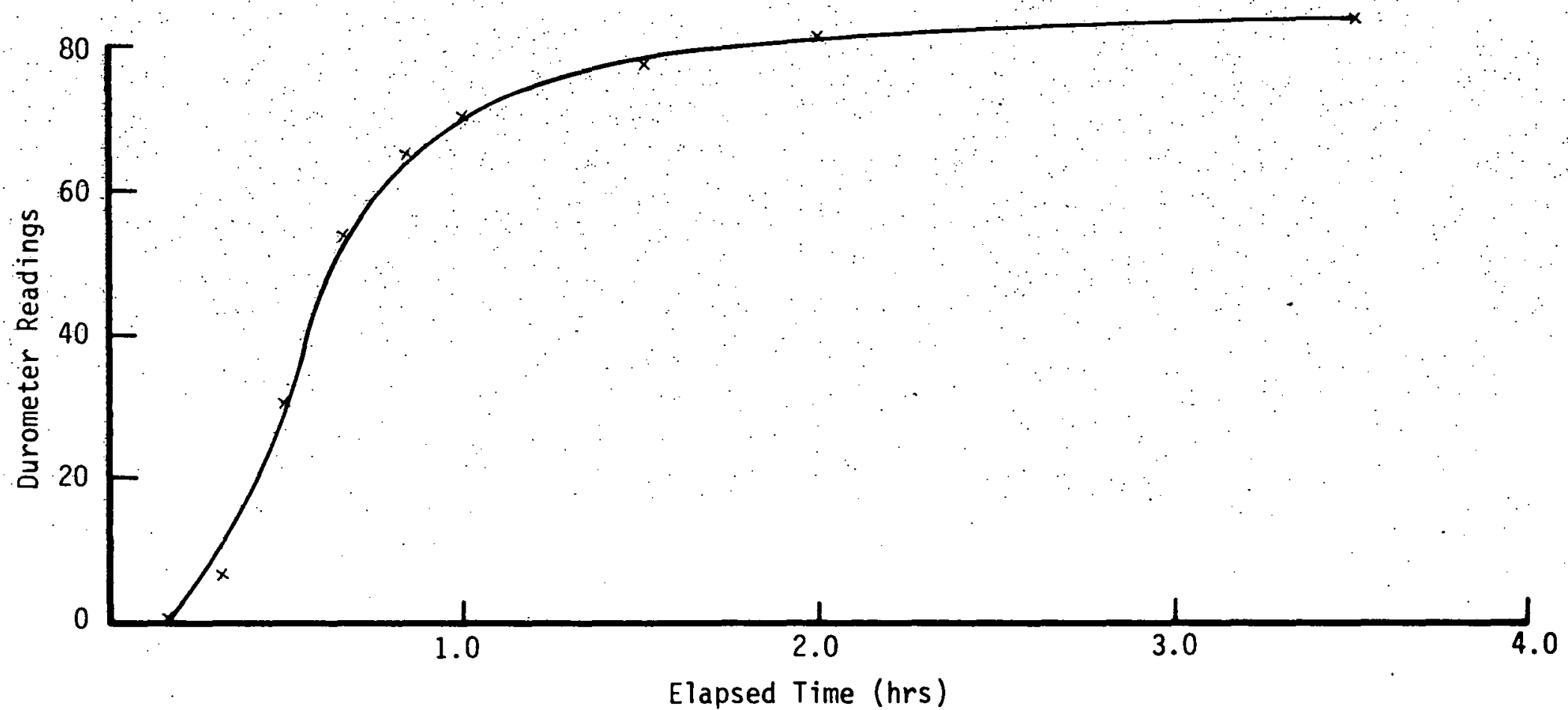

Fig. 11. LX-13 Durometer Measurements (68 C) 


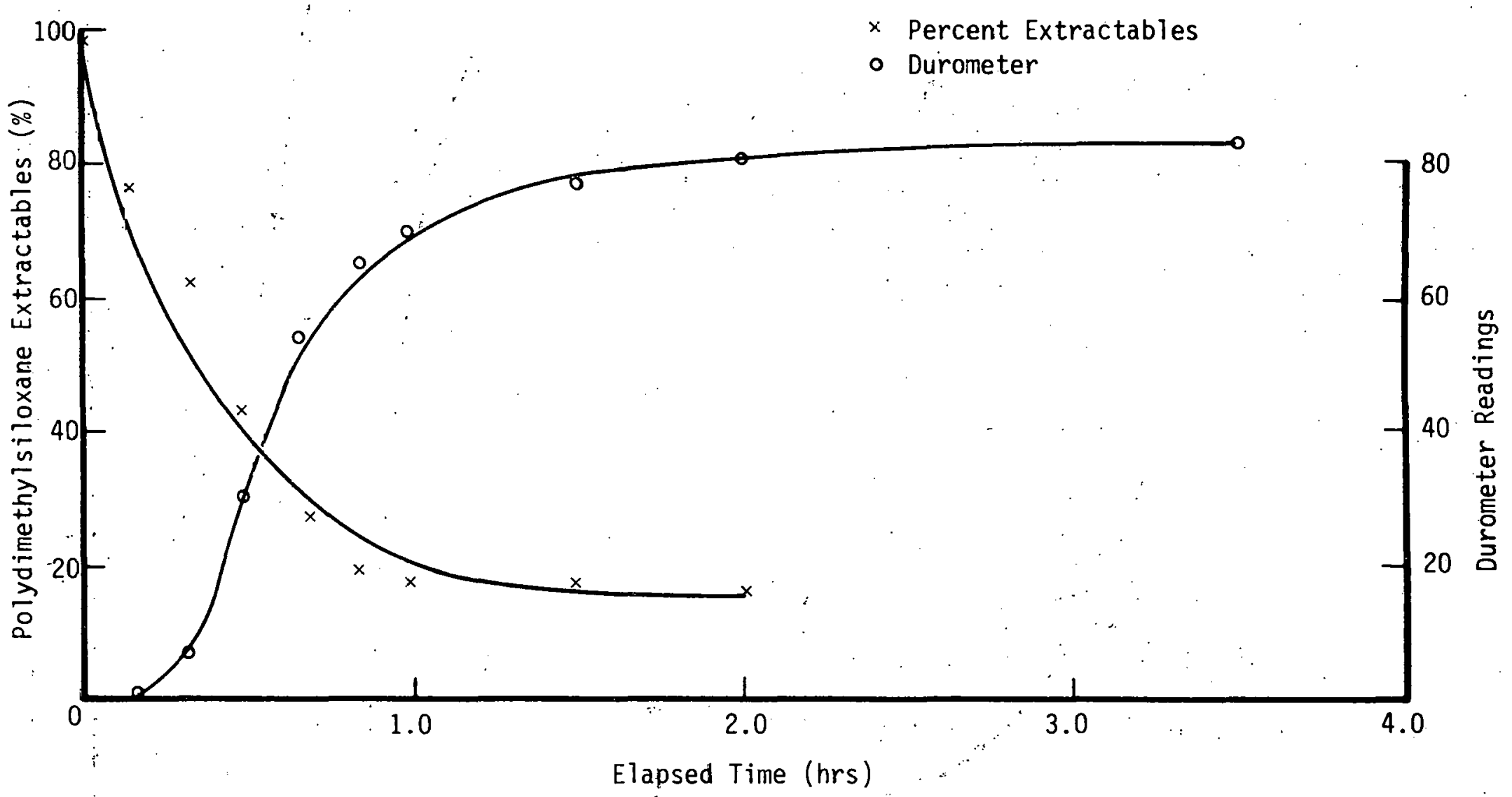

Fig. 12. LX-13 Comparison of Durometer Measurements with Percent Extractables $(68 \mathrm{C})$ 


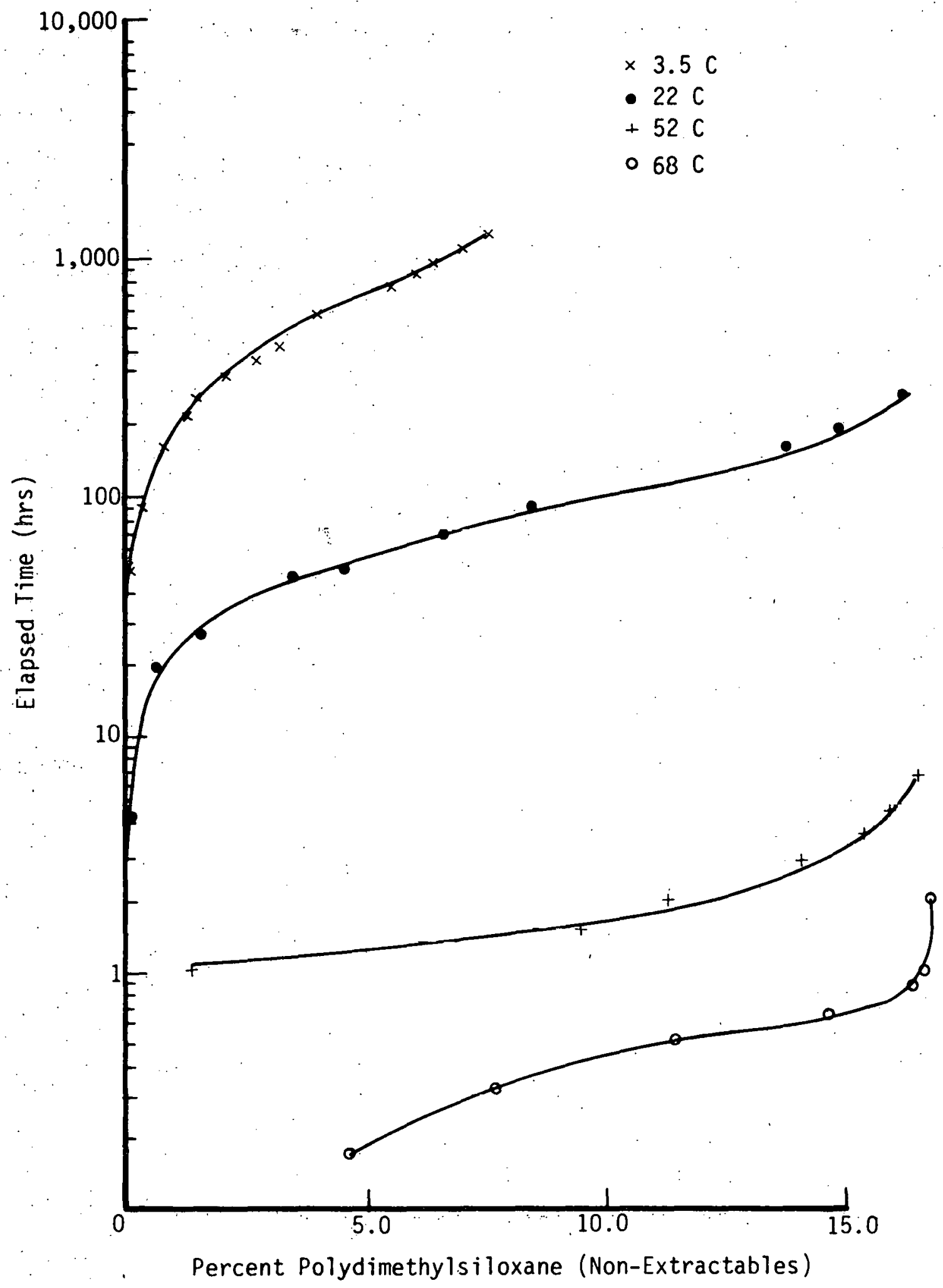

Fig. 13. Elapsed Time Versus Percent Non-Extractables 


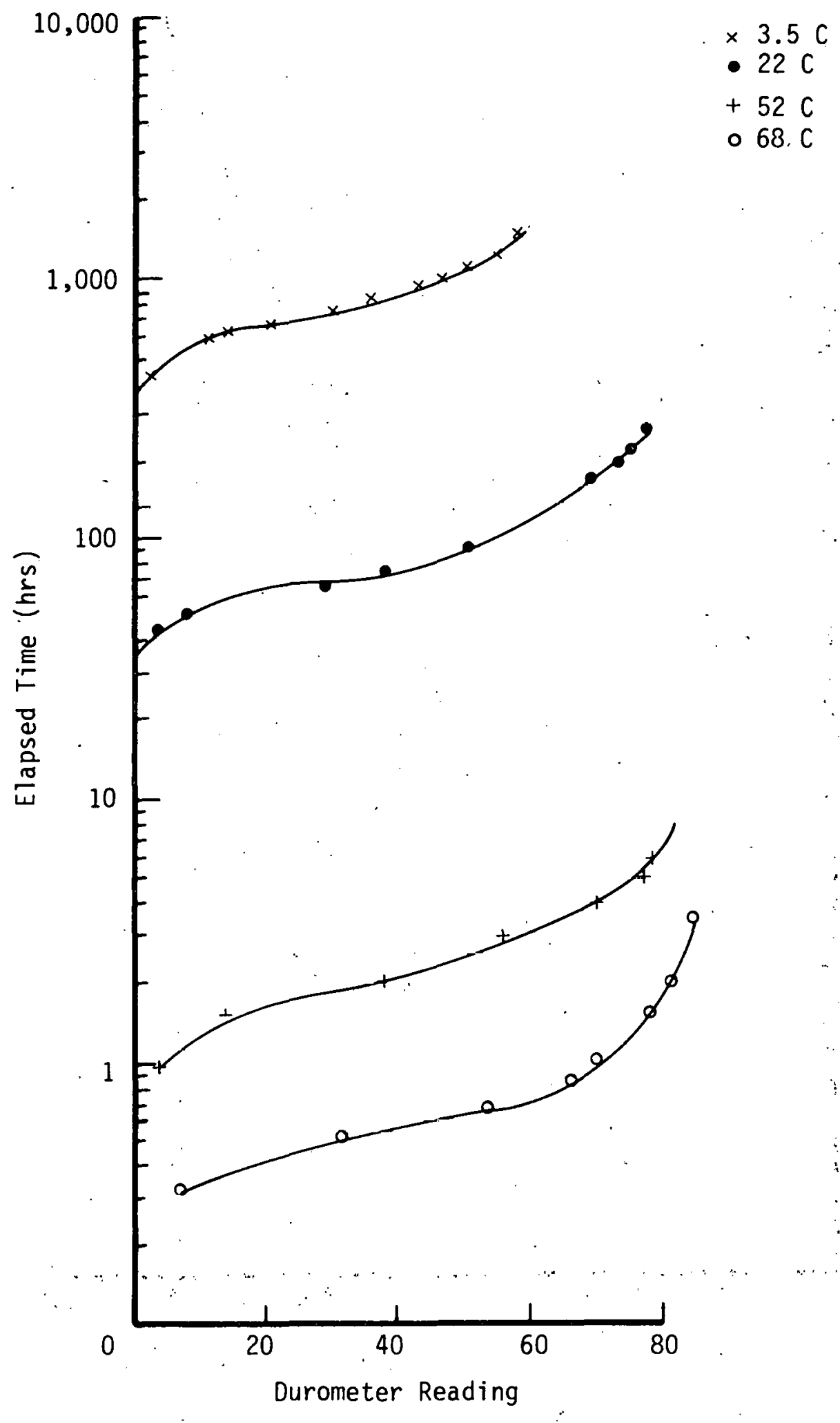

Fig. 14. Elapsed Time Versus Durometer Hardness 


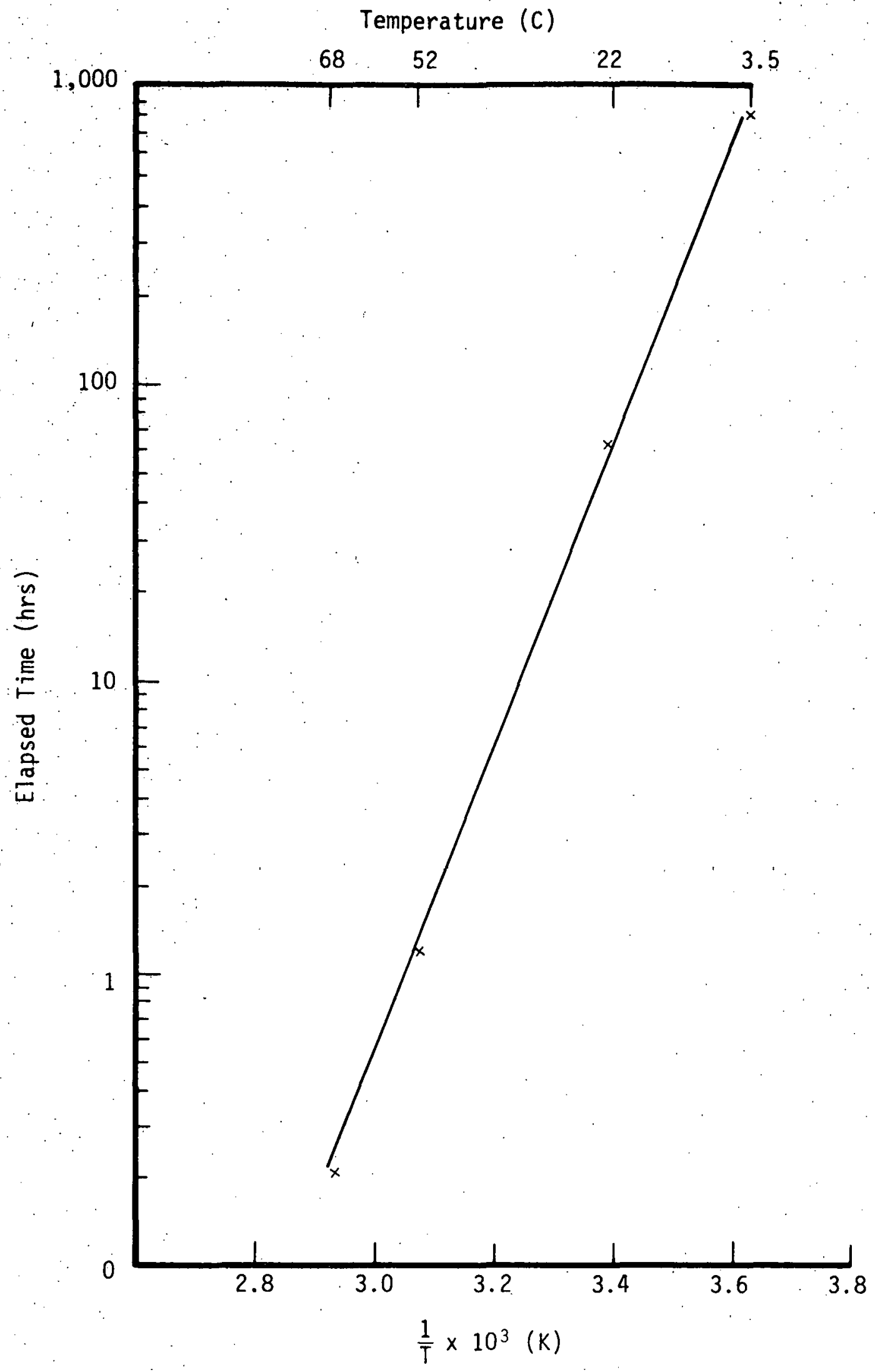

Fig. 15. Time Versus Reciprocal Temperature at $30 \%$ Extractables Cure Point 